\title{
THE ROLE OF FACEBOOK AS A SOCIAL MEDIA MARKETING ON HOUSEWIVES' START-UP BUSINESS
}

\author{
Ludi Wishnu Wardana \\ Faculty of Economics Universitas Negeri Malang
}

\begin{abstract}
Social media marketing is one of several marketing models, and as the name suggests, it utilizes social media, which is used by most people nowadays, to market or promote a product, a service, a brand, or an issue. This study aims to analyze how influential is the role of Facebook to several housewives' start-up business. This study uses qualitative approach, which utilizes interviews in order to understand the marketing strategy through social media that is implemented by several housewives' start-up business. The marketing strategy that is implemented by these housewives' start-up business corresponds with developments in the current age, in which everything is IT-based. The Facebook as a social media marketing that these housewives' start-up business implement can be categorized as a good marketing strategy. This can be proven with the achievement of outputs that are created during the implementation of these housewives' social media marketing strategy and with positive impacts that this strategy has created, especially on the increase of productivity, profit, competitiveness, and competence, as well as on the creation of a good image among their enterprises. However, the problem for these housewives' start-up business comes from their own inactivity in the marketing process, and this affects their customers as the customers find it hard to find information about these enterprises. Thus, it can be concluded that the marketing strategy that these housewives' start-up business implement, which is social media marketing, has an important role in the success of their enterprises.
\end{abstract}

Keywords: social media marketing, Facebook, housewives' start-up business

\section{INTRODUCTION}

Nowadays businesses develop very fast and advance, a situation which we can see in the growth of new thriving enterprises every year. This has lead every entrepreneur and every person working in enterprises to improve and develop their marketing programs to an extent in which products win customers' hearts and minds.

"The electronic social media such as Twitter, Facebook, MySpace, etc. have become a major form of communication, and the expression of attitudes and opinions, for the general public" (Branthwaite \& Patterson, 2011, p. 430).

*Corresponding Author.

e-mail: ludi.wishnu.fe@um.ac.id
The usage of electronic social media is increasing daily (Scholtz et. al., 2017). By using the electronic social media, users enable to interact (i.e., communicate and collaborate) with each other in distributing content (i.e., media and text) (Scholtz et. al., 2017). The value of the electronic social media is due to interactions between users (Xu et al., 2012; Scholtz et. al., 2017).

The electronic social media has become an important media for marketing, because media for marketing has shifted from traditional media marketing to social media marketing (Duffett, 2015). Further, advertizing budget of social 
Ludi Wishnu Wardana / The Role of Facebook as a Social Media Marketing on Housewives' Start-Up Business /

JEE, Vol. 7, No. 2, September 2018, pp 79-86

media marketing has become a larger portion than traditional media marketing (Saxena \& Khanna, 2013; Duffett, 2015). Furthermore, Facebook's revenue from advertizing in the second quarter of 2017 is USD 9.16 billion (Swant, 2017). The revenue increases a 47 percent over the same quarter in 2016 (Swant, 2017). In addition, Facebook was the most frequently used than YouTube, Twitter, LinkedIn, MySpace (e.g., Scholtz et. al., 2017).

"About 80 percent of small business owners use Facebook for marketing" (Pilon, 2017). When one uses social media as a platform for marketing, there are several things that one should be consider. The first is being active to promote the products in the media, the second is considering to build relation with targetted customers before aggresively market products and services to them, the third is involving the users in the media, the fourth is utilizing e-mail to process product purchases (e.g., He et al., 2017).

This study is aimed to obtain clear information regarding the influence of the role of Facebook to several housewives' start-up business, and eventually to be one source of consideration in marketing in social media for start-up enterprise (i.e., small business).

\section{METHOD}

According to the problems that are being studied, this study was conducted with a qualitative approach. The data were obtained directly through interviews with the informants. Series of interviews were given to the housewives' start-up business in order to obtain enough information regarding the role of facebook as a social media marketing. They are the owners of their start-ups in Mojokerto,
East Java, Indonesia. In addition, SWOT analysis was done to identify the strategy of housewives' start-up business.

The analysis was done by starting interview processes, which were done intensively with the informants. In this case, the informants are well informed and posess insight on the situation of an object of the study. After the interview, the analysis was started by arranging the transcripts from the interviews, in which the researcher played the recorded version of the interviews and at the same time listened to the recordings carefully and thoroughly. Then the researcher arranged words from recording in order to provide a better presentation from the result of the interviews. After the result of the interviews were written and arranged in a transcript, there were several things that the researcher had to do, which are: data reduction and data display. In finding the legitimacy of the findings, the researcher applied the source/informant triangulation. Source triangulation is a method in which the researcher gives interviews to several sources of data who are the owners of the start-ups, the housewives, and the customers.

\section{RESULTS AND DISCUSSION}

According to the result of SWOT matrix (Table 1), there is a need for a strategy for these housewives' start-up business in facing the competition. There are selected strategies for this, which are diversification and effective utilization of social media marketing. To expand the market, one should consider in creating new varieties of products with various different prices, from high-end products down to lowend counterparts, so that every segment or everybody can purchase the products. The uti- 
Table 1 SWOT Analysis of the Housewives' Start-Up Business

\begin{tabular}{|c|c|c|}
\hline External Factor & $\begin{array}{l}\text { Strenghts (S) } \\
\text { - Good product } \\
\text { quality (quality } \\
\text { veils/hijabs that are } \\
\text { compatible with the } \\
\text { current era). } \\
\text { - Strong and neat } \\
\text { tailoring. } \\
\text { - Affordable price. } \\
\text { - Good and fast } \\
\text { customer service. }\end{array}$ & $\begin{array}{l}\text { Weakknesses (W) } \\
\text { - Lack in product } \\
\text { variety (limited only } \\
\text { to veils/hijabs sales). } \\
\text { - } \quad \text { Lack in product } \\
\text { availability.s } \\
\text { - No clear } \\
\text { organizational } \\
\text { structure. } \\
\text { - Minimal marketing } \\
\text { effort. }\end{array}$ \\
\hline $\begin{array}{l}\text { Opportunities }(\mathrm{O}) \\
\text { - Increasing needs among } \\
\text { the populace to wear } \\
\text { veils/hijabs. } \\
\text { - Creation of new products } \\
\text { in the future. } \\
\text { - Complex market target } \\
\text { (market target that covers } \\
\text { every segments). } \\
\text { - Sales increase. } \\
\text { - Indonesia's demographics } \\
\text { (a country where the } \\
\text { majority is Muslim, thus } \\
\text { having high demand on } \\
\text { veils/hijabs). }\end{array}$ & $\begin{array}{l}\text { SO Strategy } \\
\text { - Utilizing resources } \\
\text { to create new } \\
\text { products. } \\
\text { - } \text { Establishing a free } \\
\text { shipping program } \\
\text { with COD (Cash on } \\
\text { Delivery) to reach } \\
\text { the nearest } \\
\text { customers. }\end{array}$ & $\begin{array}{l}\text { WO Strategy } \\
\text { - } \\
\text { ostablishing an } \\
\text { offline shop to } \\
\text { maximize market } \\
\text { target. } \\
\text { - Maximalizing } \\
\text { promotion in social } \\
\text { media to ease future } \\
\text { customers to obtain } \\
\text { information, and } \\
\text { thus increasing the } \\
\text { sales. }\end{array}$ \\
\hline $\begin{array}{l}\text { Threaths }(\mathrm{T}) \\
\text { - New competitors with } \\
\text { better concepts. } \\
\text { - Competitors that have } \\
\text { been established long } \\
\text { before and have gained } \\
\text { popularity. } \\
\text { - Price instability for raw } \\
\text { materials. }\end{array}$ & $\begin{array}{l}\text { Strategi ST } \\
-\quad \text { Maintaining the } \\
\text { quality and } \\
\text { consistantly } \\
\text { prioritizing on } \\
\text { quality tailoring. } \\
\text { - Improving the } \\
\text { quality of the } \\
\text { service. }\end{array}$ & $\begin{array}{l}\text { Strategi WT } \\
\text { Increasing the } \\
\text { amount of product } \\
\text { to be displayed on } \\
\text { the social media } \\
\text { account of the } \\
\text { enterprise. }\end{array}$ \\
\hline
\end{tabular}

lization of social media marketing through Facebook can effectively ease customers to receive information gradually and also create among the customers an interest to buy the products.

This discussion is generated from the results of interviews as well as the SWOT analysis (Table 1) to create a credible suggestion. The housewives' start-up business have a market segmentation consisting of teenagers and young mothers. The housewives position themselves as the owners of new start-ups with a modern concept and consistantly paying attention to convenience and the quality of their products. After resolving their segmeting, targeting, and positioning processes, the housewives' start-up business apply their social media marketing strategy on Facebook for their products. The following are the discussion regarding the details of their social media marketing. 
Ludi Wishnu Wardana / The Role of Facebook as a Social Media Marketing on Housewives' Start-Up Business /

JEE, Vol. 7, No. 2, September 2018, pp 79-86

\section{Raised Brand Awareness}

Brand awareness can be categorized as one form of targeted output determined by the marketers. Enterprises advertise in social media in order to raise awareness (Taylor et al., 2011; Moriansyah, 2015). In addition, enterprises also appoint brand ambassador for their advertising effort in social media. The housewives' start-up business utilize social media, primarily Facebook, in their marketing process. They also utilize other social media platforms as well in order to maximalize their marketing effort and to make it more effective and efficient to raise more awareness. An interview with an owner states that

"I think that everybody, from kids up to elders, uses social media, and also that the social media is the right way to raise brand awareness because of its wider reach compared to the print media whose reach is rather narrow".

To maintain their sales level and win in the competition of this veil/hijab industry, the housewives' start-up business keep utilizing social media to win the hearts and minds of the community where they operate and to raise awareness of the existence of their products. That strategy is very effective in terms of raising the awareness of the products amont the community and attracting people to buy their products.

\section{Reputation Improvement}

By establishing a good and effective communication with the customers, and subsequently inviting the customers to actively communicate with the brand, a bond between a brand and the customers can be formed, which eventually lead to an increase in the reputation of a brand or an enterprise. Moreover, there is an explanation suggesting that customers that have experienced good service from an enterprise or quality brand can increase the chance of customers giving online Word-of-Mouth (WOM) marketing. That corresponds with the concept of viral marketing, in which customers give their own opinions and share their own experiences. Online WOM marketing has a good potential as a tool to communicate what the marketers want to market. Similarly, an excerpt from an interview with an owner also states that

"Social media has an enormous impact on
marketing. People usually call that viral
marketing, right? This viral marketing is
one of many tools to establish a good
reputation of a product. As our products
become more popular, the chance that we
can sell more products will increase
greatly".

Referring to the excerpt above, the utilization of social media is very significant in adding values to customers in influencing the formation of a product image, which later will influence customers to buy the products. Moriansyah (2015) suggest that if an enterprise actively uses social media, there is a chance to answer questions and to give responses to customers, a chance which can improve the reputation of the products or an enterprise's brand if done correctly. Therefore, an enterprise must have a resemblence of good and proper management in managing its online reputation well.

\section{Relation Improvement}

In relation to marketing, improving relation is one of the main goals of marketing on social media, a platform in which improving 
relation will give the customers convenience and a sense of value. By giving fast responses, customers feel appreciated and then can easily obtain information regarding the products, and eventually the urge to buy products from the housewives' start-up business can emerge in accordance with what the customers want. This corresponds with and is supported by an excerpt of an interview with an informant (an owner), regarding improving good relation between an enterprise and customers, and the excerpt is as follows,

"Establishing a good relation with the customers is a very important thing for business. I realize that the way to establish a good relation in the cyberspace is to give good and fast responses to what the customers ask, thus, making the customers feel easy to ask around, feel appreciated, and also making a good impact to buy our products".

That corresponds with Moriansyah (2015), which suggests that interraction between an organization with customers through social media can influence an increase in the quality of a brand relationship.

\section{Brand Development}

Social media can give all information that an enterprise requires in the process of developing its brand, its image, or its products. An enterprise can conduct an analysis from those information, and formulate that into knowledge that is able to give a contribution in developing its brand or products. That corresponds with an excerpt from an interview with an owner, which is as follows,

"Nowadays people involve social media in their lives, and that includes finding infor- mation related to trends or a fashion style of hijab. On social media, I can understand what hijab fashion is now trending in the community, and also understand what the people want in the innovation of that hijab trend.

To maintain the existence of a product, the product must be oriented to what the customers want and to the progression of the era, and those two aspects are the key to success. This corresponds with Moriansyah (2015), which suggests that a strategy for brand innovation for an enterprise which relies on social media to obtain information regarding its customers is heavily influenced by the social media itself.

\section{Increased Purchase Intention}

Enterpreneurs utilize social media to influence customers to buy their products by giving appealing information to gain sympathy from the customers. Nowadays, people tend to shop actively on the internet, which we can see from the amount of people that follow these housewives' start-up business on Facebook despite the fact that these housewives' start-up business has recently just started to operate. This also corresponds with an excerpt from an interview with an owner, which is as follows,

"Because in this digital era, social media plays a major role in many aspects, everything can easily get viral. That way, it is easier to attract as much people as possible, creating attraction for the community. That also applies in products. If many people have talked a lot about the products or the products have won their hearts and minds, there is chance for an increase in sales or the number of return customers". 
Ludi Wishnu Wardana / The Role of Facebook as a Social Media Marketing on Housewives' Start-Up Business /

JEE, Vol. 7, No. 2, September 2018, pp 79-86

Everything that these housewives' start-up business do related to marketing on social media is related to obtain loyal customers who are willing to buy more products from these housewives' start-up business and to wait for latest information related to them. This also corresponds with Moriansyah (2015), suggesting that the attitude from the customers towards a product can be influenced by peer influence, by improving a positive attitude towards a product that can raise the intensity for the customers to buy that product.

\section{CONCLUSIONS}

The marketing strategy that these housewives' start-up business implement is compatible with the current era, in which everything is IT-based. The application of social media marketing by these housewives' start-up business can be categorized as a good marketing strategy, which can be proven by the amount of output that has been achieved during the marketing process on social media.

Social media marketing that these housewives implement in their start-ups raises brand awareness among the customers of their products. By utilizing social media, their marketing strategy is able to raise brand awareness of their products considering the fact that the customers are on the internet, a cyberspace in which we all can market products to any kinds of customers in a wider area.

When an enterprise is active on social media, there is a chance to answer all the questions and to respond to all customers that are able to improve the reputation of the products or the enterprise itself. Social media enables us to communicate anywhere in the world and at any time. In addition, in to achieve their goal to be the top brand for hijab and outfit among hijab-wearing women, their utilization of social media can be considered effective enough in improving the reputation of the enterprise.

A good relation with customers is an important thing in marketing strategy, because social media enables people or parties to communicate with each other. Interractions between sellers and customers have a high chance to influence the quality of brand relationship because of emotional influence that makes customers feel appreciated shown in answers for their questions and responses from the enterprises. This is very effective because of the convenience that social media provide such as being able to be accessed by anybody anywhere in the world and at anytime.

Social media influences the development of a brand that follows and adjusts itself to the demands, or even customers' preferences. This process has been made easier by social media because it provides information regarding customer behaviours and needs. With the existence of this easy information from social media, enterprises may face no more difficulties in innovating and developing their products.

In this digital era, social media can influence a decision-making process from the customers, including their decision to buy a product. The housewives' start-up business, of course, put that situation into their advantage by providing information that can attract sympathy from both return customers and furture customers to buy their products. This is very effective because the majority of the customers are active on social media.

Suggestions for the housewives' start-up business: (1) be more active in promoting the products, considering the fact that they are still 
start-up, on social media while also affiliating their products with celebrities or influential people to attract more sympathy from the customers; (2) add more products to be displayed on the Facebook accounts of these housewives' start-up business to attract more attention and to add more variety of potential customers; (3) give appealing offers such as discounts or special prices to create more interest among the customers; and (4) if possible, establish a shop or a boutique to accomodate demands from loyal customers in Mojokerto and its surrounding areas.

\section{REFERENCES}

Branthwaite, A. \& Patterson, S. 2011. The Power of Qualitative Research in the Era of Social Media. Qualitative Market Research: an International Journal, 14(4), 430-440.

Duffett, R.G. 2015. Facebook Advertising's Influence on Intention-to-Purchase and Purchase Amongst Millennials. Internet Research, 25(4), 498-526.

He, W., Wang, F.K., Chen, Y., \& Zha, S. 2017. An Exploratory Investigation of Social Media Adoption by Small Businesses. Information Technology and Management, 18(2), 149-160.

Moriansyah, L. 2015. Pemasaran Melalui Media Sosial: Antecedents dan consequences.
Jurnal Penelitian Komunikasi dan Opini Publik, 19(3), 187-196.

Pilon, A. 2017. 80 Percent of Small Businesses Use Facebook for Marketing, New Survey Says. Retrieved from https://smallbiztrends.com/2017/09/top-social-media-sitesfor-marketing-small-business.html.

Saxena, A. \& Khanna, U. 2013. Advertising on Social Network Sites: A Structural Equation Modelling Approach. Vision, 17(1), $17-25$.

Scholtz, B., Calitz, A.P., \& Tlebere, T. 2017. Evaluating Students' Social Media Use for Extra-Curricular Education. Journal of Applied Research in Higher Education, 9(1), 5-23.

Swant, M. 2017. Facebook Raked in $\$ 9.16$ Billion in ad Revenue in the Second Quarter of 2017: It Now has 1.32 Billion Daily Active Users. Retrieved from https:// www.adweek.com/digital/facebook-rakedin-9-16-billion-in-ad-revenue-in-the-second-quarter-of-2017/

Taylor, D.G., Lewin, J.E., \& Strutton, D. 2011. Friends, Fans, and Followers: do ads Work on Social Networks?: How Gender and Age Shape Receptivity. Journal of Advertising Research, 51(1), 258-275.

$\mathrm{Xu}$, C., Ryan, S., Prybutok, V., \& Wen, C. 2012. It is Not for Fun: An Examination of Social Network Site Usage. Information \& Management, 49(5), 210-217. 
Ludi Wishnu Wardana / The Role of Facebook as a Social Media Marketing on Housewives' Start-Up Business / JEE, Vol. 7, No. 2, September 2018, pp 79-86 